\title{
Evaluation of Liver Iron Content by Magnetic Resonance Imaging in Children with Acute Lymphoblastic Leukemia after Cessation of Treatment
}

\author{
Tedavisi Tamamlanmış Akut Lenfoblastik Lösemili Çocuklarda Manyetik Rezonans \\ Görüntüleme ile Karaciğer Demir Içeriğinin Değerlendirilmesi
}

\begin{abstract}
(D) Sezer Acar¹, (D) Salih Gözmen², (D) Selen Bayraktaroğlu³, (D) Sultan O. Acar², (D) Neryal Tahta2, (D) Yeşim Aydınok4, (D) Raziye C. Vergin²
${ }^{1}$ Dr. Behçet Uz Child Disease and Pediatric Surgery Training and Research Hospital, Department of Pediatrics, Izmir, Turkey

2Dr. Behcet Uz Child Disease and Pediatric Surgery Training and Research Hospital, Division of Pediatric Hematology and Oncology, Izmir, Turkey

${ }^{3}$ Ege University Faculty of Medicine, Department of Radiology, Izmir, Turkey

${ }^{4}$ Ege University Faculty of Medicine, Division of Pediatric Hematology and Oncology, izmir, Turkey
\end{abstract}

\section{Abstract}

Objective: There are a limited number of studies evaluating iron overload in childhood leukemia by magnetic resonance imaging (MRI). The aim of this study was to determine liver iron content (LIC) by MRI in children with acute lymphoblastic leukemia (ALL) who had completed treatment and to compare those values with serum iron parameters.

Materials and Methods: A total of 30 patients between the ages of 7 and 18 who had completed ALL treatment were included in the study. Serum iron parameters (serum iron, serum ferritin [SF], and total ironbinding capacity) and liver function tests were studied. R2 MRI was performed for determining LIC.

Results: Normal LIC was detected in 22 (63.4\%) of the cases. Seven (23.3\%) had mild and 1 (3.3\%) had moderate liver iron deposition. In contrast, severe iron overload was not detected in any of the cases. LIC levels were correlated with the numbers of packed red blood cell (pRBC) transfusions $(r=0.637, p<0.001), p R B C$ transfusion volume $(r=0.449, p<0.013)$, SF levels $(r=0.561, p=0.001)$, and transferrin saturation $(r=0.353, p=0.044)$. In addition, a positive correlation was found between the number of pRBC transfusions and SF levels $(r=0.595, p<0.001)$.

Conclusion: We showed that the frequency of liver iron deposition was low and clinically less significant after the end of treatment in childhood ALL patients. LIC was demonstrated to be related to SF and transfusion history. These findings support that SF and transfusion history may be used as references for monitoring iron accumulation or identifying cases for further examinations such as MRI.

Keywords: Acute lymphoblastic leukemia, Iron overload, Complications, Pediatric leukemia

\section{Öz}

Amaç: Çocukluk çağı lösemisinde aşırı demir yükünü manyetik rezonans görüntüleme (MRG) ile değerlendiren sınırlı sayıda çalışma vardır. Bu çalışmanın amacı, akut lenfoblastik lösemisi (ALL) olan ve tedavisini tamamlamış olan çocuklarda R2 MRI yöntemiyle karaciğer demir içeriğini (LIC) belirlemek ve serum demir parametreleriyle karşılaştırmaktır.

Gereç ve Yöntemler: Çalışmaya ALL tedavisini tamamlayan 7-18 yaşları arasında toplam 30 hasta alındı. Serum demir parametreleri (serum demir, serum ferritin [SF] ve toplam demir bağlama kapasitesi), karaciğer fonksiyon testleri çalışıldı. LIC'yi belirlemek için R2 MRG yöntemi kullanıldı.

Bulgular: Olguların 22'sinde $(\% 63,4)$ normal LIC saptandı. Yedi $(\% 23,3)$ olguda hafif ve $1(\% 3,3)$ olguda orta derecede karaciğerde demir birikimi mevcuttu. Buna karşılık, hiçbir olguda ciddi derecede demir birikimi tespit edilmedi. LIC seviyeleri, pRBC transfüzyonu sayısı $(r=0,637, p<0,001), p R B C$ transfüzyon miktarı $(r=0,449, p<0,013)$, SF seviyeleri $(r=0,561, p=0,001)$ ve transferrin $(r=0,353, p=0,044)$ ile korele saptandı. Ek olarak, pRBC transfüzyonlarının sayısı ile SF seviyeleri arasında pozitif korelasyon bulundu $(r=0,595, p<0,001)$.

Sonuç: Çocukluk çağı ALL hastalarında tedavi bitiminden sonra karaciğer demir birikiminin sıklığının düşük ve klinik olarak daha az önemli olduğunu gösterdik. Ayrıca, LIC'nin SF ve transfüzyon öyküsü ile ilişkili olduğunu gösterdik. Bu bulgular, SF ve transfüzyon geçmişinin demir birikimini izlemek veya MRG gibi ileri tetkikin gerekli olduğu olguları belirlemek açısından referans olarak kullanılabileceğini desteklemektedir.

Anahtar Sözcükler: Akut lenfoblastik lösemi, Demir birikimi, Komplikasyonlar, Pediatrik lösemi

๑Copyright 2020 by Turkish Society of Hematology

Turkish Journal of Hematology, Published by Galenos Publishing House

口

Received/Geliș tarihi: October 14, 2019

Training and Research Hospital, Department of Pediatrics, İzmir, Turkey

Phone : +902324116000 (6318)

E-mail : .acarsezer@gmail.com ORCID: orcid.org/0000-0002-0768-835X 


\section{Introduction}

Acute lymphoblastic leukemia (ALL) is the most common malignant neoplasm in children and adolescents [1]. Patients require frequent packed red blood cell (pRBC) transfusions, a vital supportive therapy that improves the anemic condition, due to intensive chemotherapy to achieve remission during the induction phase $[2,3]$. One milliliter of RBCs contains $1.16 \mathrm{mg}$ of iron, and therefore 1 unit of pRBC is estimated to contain about 200-250 $\mathrm{mg}$ of iron [2]. However, there is no physiological mechanism involved in the excretion of accumulated iron in the body, and iron overload becomes evident in patients transfused with over 10-20 units of pRBCs [2].

Transfusional iron first accumulates in the bone marrow and reticuloendothelial system (RES) macrophages [4]. When the storage capacity of the RES is exceeded, iron is transferred from macrophages to plasma transferrin. If the iron-binding capacity of transferrin reaches saturation, harmful iron species, such as non-transferrin bound iron (NTBI) and labile plasma iron (LPI), appear in the plasma, resulting in deposition of excess iron within mainly the liver, myocardium, and endocrine organs, which in turn provokes the formation of free radicals, leading to tissue and organ damage $[4,5]$. There are a limited number of methods that can indicate the amount of iron accumulated in the body that leads to organ damage. Although the determination of iron accumulation by liver biopsy is the most reliable method, it is generally avoided because it is an invasive procedure [6]. In addition, although the serum ferritin level is suggested to be reliable in monitoring iron accumulation in the body, it may be affected by infection or inflammatory conditions and that may lead to misinterpretation [7]. In recent years, magnetic resonance imaging (MRI) has replaced biopsy in the evaluation of body iron accumulation because it is a non-invasive, easily accessible, and reliable method, and it shows the characteristics of the whole tissue iron $[8,9]$. The principle of this method is based on the paramagnetic properties of iron. Liver iron content (LIC) is indirectly calculated according to the severity of the variability in the magnetic resonance signal caused by iron accumulation in the organ involved. In the literature, there are many studies using different MRI methods for demonstrating liver iron deposition in thalassemia, sickle cell anemia, and myelodysplastic syndrome in children and adults, and in acute leukemia in adults $[10,11,12,13,14,15]$.

There are some studies evaluating iron overload by MRI in children with hematologic malignancies, solid tumors, and hematopoietic stem cell transplantation (HSCT) $[16,17,18,19,20,21,22]$. In one these studies, liver iron accumulation was determined by the liver/muscle ratio signal intensity (L/M SI) method with lower sensitivity [17], while in other studies, acute leukemias (ALL, acute myeloid leukemia $[A M L])$ and solid tumor cases were evaluated together $[16,21]$.
In a study in which only ALL cases were evaluated, the patients were selected for determination of iron deposition by MRI according to transfusion frequency and/or ferritin level, causing a decrease in the number of cases evaluated (22 of 79 patients included in the study) [18]. Moreover, in some studies, subjects with serum ferritin levels above $1.000 \mathrm{ng} / \mathrm{mL}$ were included in the evaluation of iron overload by MRI $[19,20]$. The aim of the present study was to determine the LIC in children with ALL who had completed treatment by the R2 MRI method and to compare those values with serum iron parameters. This study differs from previous studies in that i) only ALL cases were included, ii) all children had completed treatment, and iii) the R2 MRI method was applied in all cases.

\section{Materials and Methods}

\section{Patient Selection}

A total of 32 patients between the ages of 7 and 18 who had completed ALL treatment between January 2012 and December 2013 were included in the study. Two patients were excluded from the study because they did not want to be included or due to technical errors in liver MRI. As a result, 11 females (median age: 8.2; range: 7.1-17.2 years) and 19 males (median age: 7.5; range: 7.1-15.7 years) were included in the study. According to the ALL BFM 2009 protocol, 13 patients were in the standard-risk $(\mathrm{SR}), 15$ were in the intermediate-risk (IR), and 2 were in the highrisk (HR) group. Patients younger than 7 years of age, those who were noncompliant with the commands during MRI, and those with mental retardation, fear of tight spaces (claustrophobia), or hepatitis were excluded from the study. This study was approved by the Ethics Committee of Dr. Behçet Uz Children's Hospital in İzmir, Turkey, in accordance with the Declaration of Helsinki (date/number: 12.12.2011/72). All of the children and/or their parents gave written informed consent before the study.

The numbers of pRBC transfusions and the transfusion volumes received during the treatment period were recorded. At the end of treatment, serum iron parameters (serum iron, serum ferritin $[S F]$, and total iron-binding capacity [TIBC]), liver function tests (alanine transaminase [ALT], aspartate transaminase [AST], albumin, total bilirubin, direct bilirubin), prothrombin time (PT), and partial thromboplastin time (APTT) were studied. SF levels were determined by a chemiluminescent microparticle immunoassay (Abbott, Architect i2000) and serum iron and TIBC were determined with an Abbott Architect c1600 autoanalyzer. Transferrin saturation was calculated by dividing serum iron into TIBC and expressed as a percentage. At the same time as the evaluation of serum iron profile, R2 MRI was performed in the Ege University MRI Unit in İzmir for determining LIC. MRI evaluations were performed 1-5 months (median: 3 months) after the end of treatment. Serum iron, SF, and TIBC levels and transferrin saturation calculations were repeated after an 
interval of 9-13 months (median: 11 months) for patients with high SF levels ( $>500 \mathrm{ng} / \mathrm{mL}$ ) detected in the first evaluation.

\section{Magnetic Resonance Imaging and Liver Iron Content Analysis}

All MRI examinations of the liver were performed with a 1.5-T scanner (Symphony, Siemens, Erlangen, Germany) using body and head coils, respectively. Liver-R2 values of the ALL patients were measured. To calculate liver-R2, liver images were collected from the same respiratory-triggered slices of axial multi-echo SE sequences (TR: $300 \mathrm{~ms} ; \mathrm{TE}: 3.8,6,9,12,15$, and $18 \mathrm{~ms}$; slice thickness: $10 \mathrm{~mm}$; matrix size: $80 \times 256$; FOV: $42 \mathrm{~cm}$ ). The scan durations were $84 \mathrm{~s}$ each.

MRI images of the liver were initially examined in order to exclude the presence of any mass lesions. Afterwards, the echo images of the pituitary gland and liver were exported from the scanner in DICOM-3 format and imported to dedicated software that cooperates with MATLAB (MathWorks, Natick, MA, USA). A mono-exponential function of the formula $\mathrm{S}(\mathrm{TE})=$ So $\mathrm{x} \exp (-$ $T E \times R 2)+C$ was used as a representative of the signal decay with echo time (TE), where S(TE) is the signal at TE. Therefore, the signal amplitude at TE is 0 , and $C$ is the constant offset parameter added to compensate for background noise bias $[23,24]$. To assess hepatic iron accumulation, the largest region of interest (ROI) was drawn around the entire liver boundary of the first echo, excluding hilar vessels, the vena cava inferior, and motion artifacts. The ROI was copied to all images of the corresponding echoes. R2 evaluation of the liver was performed with the same analytic tool using the same MATLAB equations. The corresponding R2 maps of the liver were derived. The mean and median R2 values and standard deviations were calculated. The mean R2 value within the liver was then used to yield a mean LIC using a calibration curve that had been determined through the measurement of the liver R2 and needle-biopsy LIC [8]. Analysis of all MRI examinations was performed by the same experienced radiologist.

The LIC values obtained for patients were classified according to the levels defined by Olivieri and Brittenham [4] in thalassemia patients. Accordingly, LIC was evaluated as normal for values of $<3.2 \mathrm{mg} / \mathrm{g}$ dry weight (d.w.), as mild iron overload for values of $3.2-7.0 \mathrm{mg} / \mathrm{g}$ d.w., as moderate iron overload for values of 7.0$15.0 \mathrm{mg} / \mathrm{g} \mathrm{d}$ d.w., and as severe iron overload for values of $>15$ $\mathrm{mg} / \mathrm{g} \mathrm{d} . \mathrm{w}$.

\section{Statistical Analysis}

Statistical analyses of the data were conducted with SPSS 20.0 (IBM Corp., Armonk, NY, USA). The distribution of the data was evaluated with the Shapiro-Wilk test. For numerical comparisons, independent sample t-tests or Mann-Whitney $\mathrm{U}$ tests were used according to the normal distribution of the measured parameters. In the comparison of two dependent groups (alterations in iron parameters during follow-up), paired t-tests or Wilcoxon rank tests were performed according to the normal distribution of the parameters. Spearman's rho correlation was used to identify the associations between variables. Categorical data were expressed as frequency (\%), while numerical data were expressed as median $\left(25^{\text {th }}-75^{\text {th }}\right.$ percentiles) or mean \pm standard deviation. In all statistical tests, $p<0.05$ was considered significant.

\section{Results}

Thirty patients ( 11 females, 19 males; median age: 7.8 years) were included in the study. Thirteen patients were in the SR group, 15 were in the IR group, and 2 were in the HR group. The median transfusion number was $12\left(25^{\text {th }}-75^{\text {th }}\right.$ percentiles: $\left.8-16\right)$ and the median SF value was $454.5\left(25^{\text {th }}-75^{\text {th }}\right.$ percentiles: 120 894). In 6 patients, the SF values were between 500 and 1.000 $\mathrm{ng} / \mathrm{mL}$, and 4 had SF levels above $1.000 \mathrm{ng} / \mathrm{mL}$. ALT, AST, total bilirubin, direct bilirubin, albumin, PT, APTT, and INR values were within the normal ranges in all patients. The median LIC was $2.77 \mathrm{mg} / \mathrm{g}$ d.w. $\left(25^{\text {th }}-75^{\text {th }}\right.$ percentiles: 1.28-3.43) (Table 1).

Normal LIC $(<3.2 \mathrm{mg} / \mathrm{g}$ d.w.) was detected in $22(63.4 \%)$ of the patients. Seven (23.3\%) had mild (3.2-7.0 mg/g d.w.) and $1(3.3 \%)$ had moderate $(8.47 \mathrm{mg} / \mathrm{g}$ d.w.) liver iron deposition. Severe iron overload was not detected in any of the cases.

Table 1. Evaluation of age, transfusion history, serum iron parameters, and LIC data of the patients included in the study.

\begin{tabular}{|c|c|}
\hline Parameters & Values \\
\hline Age (years) & $7.8(7.1-17.2)$ \\
\hline Number of RBC transfusions & $12(8-16)$ \\
\hline Total RBC transfusion amount (mL) & $2630(1730-5180)$ \\
\hline Serum iron $(\mu \mathrm{g} / \mathrm{dL})$ & 94.5 (78.0-129.7) \\
\hline Total iron-binding capacity $(\mu \mathrm{g} / \mathrm{dL})$ & $332.9 \pm 55.3$ \\
\hline Serum ferritin (ng/mL) & $454.5(120.0-894.0)$ \\
\hline Transferrin saturation (\%) & $27.7(17.7-36.4)$ \\
\hline AST (IU/L) & $27(23.8-34.5)$ \\
\hline ALT (IU/L) & $19.9(15.0-26.3)$ \\
\hline Total bilirubin (mg/dL) & $0.52(0.44-0.70)$ \\
\hline Direct bilirubin (mg/dL) & $0.08(0.01-0.10)$ \\
\hline Albumin $(\mathrm{g} / \mathrm{dL})$ & $4.15 \pm 0.37$ \\
\hline Prothrombin time (PT) (s) & $12.7 \pm 0.60$ \\
\hline Partial thromboplastin time (APT) (s) & $29.8 \pm 2.92$ \\
\hline International normalized ratio (INR) & $1.09 \pm 0.06$ \\
\hline LIC (mg/g dry weight liver) & $2.77(1.28-3.43)$ \\
\hline \multicolumn{2}{|c|}{ Data are given as mean \pm SD or median (IQR $25^{\text {th }}-75^{\text {th }}$ percentiles). } \\
\hline \multicolumn{2}{|c|}{$\begin{array}{l}\text { RBC: Red blood cell; AST: aspartate transaminase; ALT: alanine transaminase; LIC: liver } \\
\text { iron content. SD: Standard deviation }\end{array}$} \\
\hline
\end{tabular}


The characteristics of the patients with mild to moderate liver iron overload are summarized in Table 2.

When the patients were divided into two groups according to LIC levels, the numbers of pRBC transfusions, total pRBC transfusion volumes, and SF levels were significantly higher in patients with LIC of $>3.2 \mathrm{mg} / \mathrm{g}$ d.w. $(\mathrm{p}<0.05)$ (Table 3$)$. In addition, LIC levels were positively correlated with the number of pRBC transfusions $(r=0.637, p<0.001), R B C$ transfusion volume $(r=0.449, p<0.013)$, SF levels $(r=0.561, p=0.001)$ (Figure $1)$, and transferrin saturation $(r=0.353, p=0.044)$ and negatively correlated with TIBC $(r=-0.439, p<0.001)$ (Table 4). In addition, a positive correlation was found between the number of $\mathrm{pRBC}$ transfusions and SF levels $(r=0.595, p<0.001)$.

Serum iron, transferrin saturation, TIBC, and SF levels were measured again after 9-13 months (median: 11 months) for patients with high SF levels $(>500 \mathrm{ng} / \mathrm{mL}$ ) detected at the first evaluation.

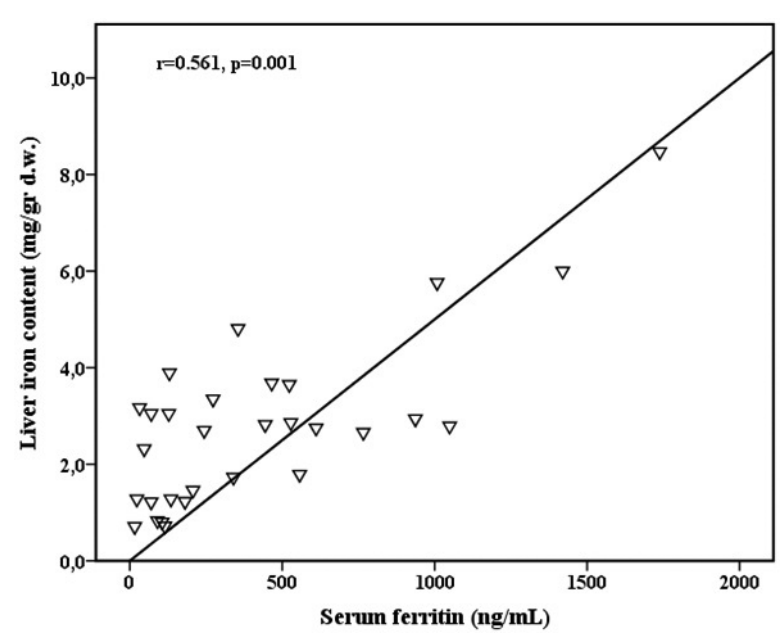

Figure 1. Demonstration of the correlation between LIC and serum ferritin levels.

\begin{tabular}{|l|l|l|l|l|l|l|l|}
\hline \multicolumn{6}{|l|}{ Table 2. Clinical and laboratory characteristics of patients with mild and moderate iron deposition. } \\
\hline Patient no. & Age (years) & Sex & Risk group & $\begin{array}{l}\text { Number of RBC } \\
\text { transfusions }\end{array}$ & $\begin{array}{l}\text { Total amount } \\
\text { of transfusions } \\
\text { (mL) }\end{array}$ & $\begin{array}{l}\text { Serum ferritin } \\
\text { (ng/mL) }\end{array}$ & $\begin{array}{l}\text { LIC (mg/g dry } \\
\text { weight) }\end{array}$ \\
\hline 4 & 17.2 & Female & IR & 18 & 12240 & 1008 & 5.76 \\
\hline 5 & 8.1 & Male & SR & 9 & 2050 & 523 & 3.65 \\
\hline 11 & 7.3 & Male & HR & 33 & 6730 & 1738 & 8.47 \\
\hline 12 & 7.9 & Male & IR & 17 & 4010 & 1420 & 6.01 \\
\hline 13 & 7.6 & Female & SR & 13 & 2600 & 273 & 3.35 \\
\hline 23 & 7.1 & Female & SR & 16 & 3360 & 130 & 3.89 \\
\hline 24 & 13.4 & Male & IR & 15 & 7950 & 355 & 4.81 \\
\hline 29 & 9.1 & Female & IR & 13 & 3420 & 465 & 3.68 \\
\hline IR: Intermediate risk; SR: standard risk; HR: high risk. LIC: Liver iron content. &
\end{tabular}

\begin{tabular}{|c|c|c|c|}
\hline \multirow[t]{2}{*}{ Parameters } & \multicolumn{2}{|l|}{ LIC (mg/g dry liver) } & \multirow[t]{2}{*}{$\mathbf{p}$} \\
\hline & $\begin{array}{l}<3.2 \\
(n=22)\end{array}$ & $\begin{array}{l}>3.2 \\
(n=8)\end{array}$ & \\
\hline Sex (female/male) & $7 / 15$ & $4 / 4$ & $0.361^{\mathrm{a}}$ \\
\hline Risk group (SR/IR/HR) & $10 / 11 / 1$ & $3 / 4 / 1$ & $0.725^{\mathrm{a}}$ \\
\hline Age (years) & 7.5 (7.2-9.3) & $8.1(7.4-12.3)$ & $0.734^{b}$ \\
\hline Number of pRBC transfusions & $9.5(8-14)$ & $15.5(13-17.5)$ & $0.018^{\mathrm{b}}$ \\
\hline Number of pRBC transfusions $(<15 />15)$ & $18 / 4$ & $3 / 5$ & $0.024^{\mathrm{a}}$ \\
\hline Total pRBC transfusion volume $(\mathrm{mL})$ & $2130(1615-4785)$ & 3715 (2790-7615) & $0.047^{b}$ \\
\hline Serum iron $(\mu \mathrm{g} / \mathrm{dL})$ & $79(54-128.5)$ & $98(72.5-125)$ & $0.237^{b}$ \\
\hline Total iron-binding capacity $(\mu \mathrm{g} / \mathrm{dL})$ & $343.2 \pm 58.8$ & $304.6 \pm 41.9$ & $0.092^{\mathrm{c}}$ \\
\hline Serum ferritin $(\mathrm{ng} / \mathrm{mL})$ & $158(70-535)$ & 494 (293-1317) & $0.024^{b}$ \\
\hline Serum ferritin $(\mathrm{ng} / \mathrm{mL})(<1000 />1000)$ & $21 / 1^{*}$ & $5 / 3$ & $0.048^{\mathrm{a}}$ \\
\hline Transferrin saturation (\%) & $24.3(14.6-35.6)$ & $32.8(25.4-40.2)$ & $0.122^{b}$ \\
\hline
\end{tabular}




\begin{tabular}{|l|l|l|}
\hline \multicolumn{3}{|l|}{$\begin{array}{l}\text { Table 4. Evaluation of the relationship between LIC and age, } \\
\text { transfusion number, iron parameters, and liver function tests. }\end{array}$} \\
\hline Parameters & $\begin{array}{l}\text { Spearman's } \\
\text { rho }\end{array}$ & $\mathbf{p}$ \\
\hline Age (years) & 0.166 & 0.381 \\
\hline Number of RBC transfusions & 0.637 & $<0.001$ \\
\hline Total RBC transfusion amount (mL) & 0.449 & $\mathbf{0 . 0 1 3}$ \\
\hline Serum iron ( $\mu \mathrm{g} / \mathrm{dL})$ & 0.232 & 0.218 \\
\hline Serum ferritin $(\mathrm{ng} / \mathrm{mL})$ & 0.561 & $\mathbf{0 . 0 0 1}$ \\
\hline Total iron-binding capacity ( $\mu \mathrm{g} / \mathrm{dL})$ & -0.439 & $<\mathbf{0 . 0 0 1}$ \\
\hline Transferrin saturation $(\%)$ & 0.385 & $\mathbf{0 . 0 4 4}$ \\
\hline AST (IU/L) & -0.031 & 0.870 \\
\hline ALT (IU/L) & 0.006 & 0.977 \\
\hline Total bilirubin (mg/dL) & -0.158 & 0.405 \\
\hline Direct bilirubin (mg/dL) & 0.020 & 0.917 \\
\hline Albumin (g/dL) & -0.027 & 0.887 \\
\hline Prothrombin time (PT) $(\mathrm{s})$ & 0.300 & 0.108 \\
\hline Partial thromboplastin time (APT) (s) & 0.308 & 0.098 \\
\hline International normalized ratio (INR) & 0.141 & 0.458 \\
\hline RBC: Red blood cell; AST: aspartate transaminase; ALT: alanine transaminase. \\
\hline
\end{tabular}

The decreases in SF levels from $773 \mathrm{ng} / \mathrm{mL}$ (508-1141) to 460

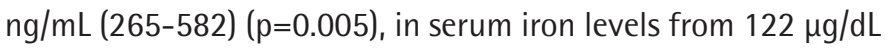
(84-142) to $71.5 \mu \mathrm{g} / \mathrm{dL}$ (57.7-91.1) $(\mathrm{p}=0.005)$, and in transferrin saturation from $36.5 \%(29 \%-50 \%)$ to $29 \% \quad(19 \%-34 \%)$ $(p=0.026)$ and the increase in serum TIBC from $330.1 \pm 35 \mu \mathrm{g} / \mathrm{dL}$ to $437.2 \pm 163.9 \mu \mathrm{g} / \mathrm{dL}(\mathrm{p}=0.047)$ were statistically significant.

\section{Discussion}

Anemia occurs frequently in childhood ALL cases due to the intensive chemotherapy given in the first 6 months of treatment. Therefore, iron accumulation may occur in this period due to intensive transfusions. Limited data are available for assessing iron accumulation due to transfusion in childhood acute leukemia. Although liver biopsy is considered to be the gold standard for measuring iron deposition, it has become a less commonly used method because of its invasive nature. In the current study, MRI, which is an indirect measurement method but strongly correlated with liver biopsy findings, was used for LIC determination $[8,9,11,16,17,25,26]$. Iron accumulation was not detected in most of our patients (63.4\%), while mild iron deposition was found in $23.3 \%$ of patients and moderate iron deposition was found in 1 (3.3\%). No severe iron accumulation was detected in any of the patients. In adult studies in which liver iron deposition was evaluated by MRI, moderate iron overload was reported in $50 \%$ of 88 patients with myelodysplastic syndrome and AML undergoing allogenic HSCT by Wermke et al. [14], moderate iron accumulation was identified in $22.2 \%$ of 27 patients with acute leukemia (ALL, AML) by Yassin et al. [15], and hepatic iron overload over $5 \mathrm{mg} / \mathrm{g}$ d.w. was found in $48 \%$ of 42 patients undergoing myeloablative HSCT by Armand et al. [10]. The reason for the higher incidence of moderate iron accumulation in adult cases than in our cohort is thought to be related to the fact that most of the cases in adult studies are more severe (MDS, myeloablative stem cell transplantation, $A M L$, etc.) and require more frequent transfusion. There are some studies in the literature evaluating liver iron deposition in childhood cancer by MRI. Vag et al. [17] evaluated liver iron accumulation during treatment in 15 children with acute leukemia (9 ALL, $6 \mathrm{AML}$ ) by measuring the L/M SI ratio (liver/ vertebral muscle signal intensity) by gradient-recalled echo method. They showed a significant decrease in signal intensity in the liver due to transfusion-dependent iron overload; however, they could not report an estimation for LIC due to the selected method's limitations [17]. Ruccione et al. [16] evaluated liver iron deposition by MRI in 75 children and young adults (age range: 8-25.6 years) with acute leukemia (ALL/AML; $n=33$ ) and solid tumors $(n=42)$ and high LIC levels were reported in $49.3 \%$ of the patients. In the same study, co-evaluation of acute leukemia (ALL/AML) and solid tumors prevented inferences about iron accumulation in acute leukemia. Unal et al. [18] reported 50\% liver and 27\% cardiac iron deposition in $36 \mathrm{ALL}$ patients (28 on treatment, 8 off treatment) by T2* MRI and, in addition, liver iron accumulation was demonstrated in two cases among 8 patients whose treatment had been completed. In the same study, it was concluded that the number of erythrocyte transfusions is more reliable than SF levels in screening for iron accumulation. In two different studies by Olcay et al. $[19,20]$, liver iron deposition was shown in 75\% and $40 \%$ of patients with acute leukemia (AML and ALL) with SF levels above 1000 $\mathrm{ng} / \mathrm{mL}$. It was suggested that since iron accumulation can be detected even when the erythrocyte transfusions are not intense, this accumulation may be related to the intensity of chemotherapy treatment [19]. Moreover, they reported that no association was found between serum levels of NTBI, which is thought to cause tissue damage, and oxidative stress markers (lipid hydroperoxide products and protein carboxyl groups) and liver iron deposition [20]. In another study, de Ville de Goyet et al. [21] reported that liver iron accumulation was found to be $66 \%$ in the first year and $82 \%$ in the second year in pediatric patients with hematologic malignancy or solid tumor. They also showed a close relationship between iron accumulation and the intensity of treatment received and number of transfusions. In a study conducted by Schempp et al. [22], it was shown that the frequency of iron overload in patients with a history of allogenic HSCT (25.9\%) was significantly higher than in those treated without HSCT (3.7\%) and with autologous HSCT (0\%). In our study, iron accumulation was found in $26.6 \%$ of cases (7 mild, 1 moderate), which is comparable with previous studies on childhood malignancies. All of these findings suggest that liver 
iron accumulation can be detected during treatment or may continue after cessation of treatment.

Unlike thalassemia, it is not clear how to interpret LIC values in acute leukemia patients who require RBC transfusions during the induction period of treatment. However, it is recommended that $7 \mathrm{mg} / \mathrm{g}$ d.w. be considered as a cut-off in the prediction of clinical complications $[4,13,27]$. When we evaluated the LIC results of our cohorts according to this cut-off value, we concluded that one patient (3.3\%) had iron accumulation with a risk of clinical complications. During the follow-up of that case, however, no impairment in liver function tests was observed.

The primary determinant of liver iron deposition is known to be related to the amount of transfusions administered to the patient. In our study, the number of transfusions and the total transfusion volumes were found to be significantly higher in patients with LIC of $>3.2 \mathrm{mg} / \mathrm{g}$ d.w. In addition, in the current study, LIC had a strong correlation with the number of transfusions and with the amounts of the transfusions. A similar positive relationship has been shown in many studies $[7,10,13,15,16,18,21]$. In addition, in our study, LIC levels were positively correlated with SF and transferrin saturation, while they were negatively correlated with TIBC. Many studies in children and adults with thalassemia, sickle cell anemia, MDS, and acute leukemia have reported strong correlations between LIC and SF levels $[4,10,13,14,17,23,28]$. These findings suggest that although the SF level is severely affected by inflammation and infection, it is still a good indicator for monitoring iron deposition as it is easily accessible, relatively inexpensive, and well standardized. Furthermore, efforts have been made to determine the cut-off values for SF level and transfusion numbers to estimate liver iron accumulation. In some studies, the transfusion of over 20 units of pRBCs has been suggested to be a significant indicator of severe iron accumulation $[29,30]$. Despite that, it was reported that significant iron accumulation can be detected in cases of hematologic malignancies (unlike thalassemia and sickle cell anemia) even when the number of transfusions is below 10 [31]. In addition, it has been stated that SF levels above $1000 \mathrm{ng} / \mathrm{mL}$ are good indicators of iron accumulation and can be used in clinical follow-up $[29,32,33]$. However, there are also studies suggesting that the cut-off value of SF level should be higher to predict remarkable iron accumulation with high sensitivity $[10,14]$. In one study, it was suggested that the risk of significant liver iron accumulation was low in patients who received fewer than 15 units of transfusion and whose ferritin level was found to be below $1000 \mathrm{ng} / \mathrm{mL}$ [10]. In contrast, iron accumulation was also reported in patients with SF levels below $1000 \mathrm{ng} / \mathrm{mL}[18,19]$. Iron accumulation in these cases has been suggested to be associated with increased numbers of pRBC transfusions [18] and active leukemia with its own effects or with anti-leukemic treatment [19]. Consistently, we demonstrated mild liver iron deposition in 3 patients (numbers of pRBC transfusions above 10) with SF levels below $500 \mathrm{ng} / \mathrm{mL}$ and in 1 patient (number of pRBC transfusions below 10) with SF level between 500 and $1000 \mathrm{ng} / \mathrm{mL}$. These findings suggest that iron accumulation can be detected even when the SF level is lower than the estimated threshold of $1000 \mathrm{ng} / \mathrm{mL}$. Moreover, in the current study, when the pRBC transfusion cut-off was assigned as 15 (sensitivity: $55.5 \%$, specificity: $85.8 \%$ ) and the ferritin level cut-off was assigned as $1000 \mathrm{ng} / \mathrm{mL}$ (sensitivity: $75 \%$, specificity: $80.8 \%$ ), a significant difference was found in terms of LIC. Although we demonstrated that LIC levels were positively correlated with the number pRBC transfusions and SF levels, it may be less misleading to estimate iron accumulation accurately by determining a clear cut-off for SF or the numbers of transfused pRBC units. Further studies with large case series are needed, taking into account the effect of the malignancy itself and the effect of chemotherapeutic agents on facilitating iron deposition.

Since ferritin levels correlate with LIC, it is widely believed that ferritin levels can be used in follow-up. In a study conducted by Halonen et al. [7] including 30 patients with ALL, they performed liver biopsy and measured serum iron parameters to determine liver iron deposition at the end of treatment, and then serum iron parameters were re-evaluated 1-3 years after the end of treatment. They reported good correlations between LIC, SF, transferrin saturation, and transfusion numbers. In the same study, it was reported that there was a statistically significant decrease in $\mathrm{SF}$, serum iron, and transferrin saturation values measured during follow-up. Similarly, in our study, control serum iron and ferritin levels and transferrin saturation were significantly decreased in patients who had high ferritin levels measured in the initial evaluation. Although excess iron accumulation in the body cannot be eliminated by any mechanism, it can be predicted that it may decrease due to the increasing need in childhood growth and development periods $[18,34]$.

Some limitations of the present study have to be acknowledged. The first limitation is that the small number of participants in the subgroup analyses might have negatively affected the results. In addition, the low number of subgroups prevented us from performing some evaluations related to ALL risk groups. For example, subgroup comparisons or correlation analyses could not be performed because most patients were in the SR and IR groups and there were only 2 in the HR group. Selection bias cannot be ruled out in this cohort because patients under 7 years of age, who cannot tolerate MRI, were not included in the study. Moreover, serum parameters were measured and MRI evaluations of patients were performed 1-5 months (median: 3 months) after cessation of treatment. Although there is no excretory mechanism for iron in the human body and so the only mechanism for its clearance is through epithelial sloughing, bleeding, or iron utilization by erythropoietic tissue [35], the 
period between the end of treatment and MRI assessment might cause slight clearance of liver iron and lower LIC measurements. Finally, various hemochromatosis gene polymorphisms that lead to mild and moderate iron deposition and mild clinical phenotypes have been described [36]. Our patients were not evaluated in this respect. However, a significant decrease in SF levels in the follow-up period may be considered as evidence that this was not the case.

\section{Conclusion}

In this study, we have shown that the frequency of liver iron deposition was low and clinically less significant after the end of treatment in childhood ALL patients of the SR and IR subgroups. LIC was demonstrated to be related to SF and transfusion history. These findings support that SF and transfusion history may be used as references for monitoring iron accumulation or identifying cases for further examination such as MRI. However, long-term longitudinal studies with larger case series including HR patients receiving treatment are needed to establish more accurate cut-off values to confirm LIC estimation or to verify our findings.

\section{Ethics}

Ethics Committee Approval: This study was approved by the Ethics Committee of Dr. Behçet Uz Children's Hospital in İzmir, Turkey, in accordance with the Declaration of Helsinki. All of the children and/or their parents gave their written informed consent before the study (date/number: 12.12.2013/72).

Informed Consent: Informed consent was obtained from parents or legal guardians before enrollment in the study

\section{Authorship Contributions}

Surgical and Medical Practices: S.A., R.C.V., S.B., S.O.A., N.T.; Concept: S.A., R.C.V., S.G., S.B., Y.A.; Design: S.A., R.C.V., S.G., Y.A.; Data Collection or Processing: S.A., N.T., S.O.A., S.G., S.B.; Analysis or Interpretation: S.A., S.O.A., R.C.V., S.B., S.G.; Literature Search: S.A., S.O.A., N.T., Y.A.; Writing: S.A., R.C.V., Y.A., S.O.A., N.T.

Conflict of Interest: The authors of this paper have no conflicts of interest, including specific financial interests, relationships, and/or affiliations relevant to the subject matter or materials included.

\section{References}

1. Barrington-Trimis $\mathrm{JL}$, Cockburn M, Metayer C, Gauderman WJ, Wiemels J, McKean-Cowdin R. Trends in childhood leukemia incidence over two decades from 1992 to 2013. Int J Cancer 2017;140:1000-1008.

2. Gao C, Li L, Chen B, Song H, Cheng J, Zhang X, Sun Y. Clinical outcomes of transfusion-associated iron overload in patients with refractory chronic anemia. Patient Prefer Adherence 2014;8:513-517.
3. Wang D, Zhou G, Mao ST, Chen J, Liu YF. Allogeneic blood transfusion in 163 children with acute lymphocytic leukemia (a STROBE-compliant article). Medicine (Baltimore) 2019;98:e14518.

4. Olivieri NF, Brittenham GM. Iron-chelating therapy and the treatment of thalassemia. Blood 1997;89:739-761.

5. Anderson ER, Shah YM. Iron homeostasis in the liver. Compr Physiol 2013;3:315-330.

6. Wood JC. Guidelines for quantifying iron overload. Hematology Am Soc Hematol Educ Program 2014;2014:210-215.

7. Halonen P, Mattila J, Suominen P, Ruuska T, Salo MK, Makipernaa A. Iron overload in children who are treated for acute lymphoblastic leukemia estimated by liver siderosis and serum iron parameters. Pediatrics 2003;111:91-96.

8. St Pierre TG, Clark PR, Chua-Anusorn W, Fleming AJ, Jeffrey GP, Olynyk JK, Pootrakul P, Robins $E$, Lindeman R. Noninvasive measurement and imaging of liver iron concentrations using proton magnetic resonance. Blood 2005;105:855-861.

9. Wood JC, Enriquez C, Ghugre N, Tyzka JM, Carson S, Nelson MD, Coates TD. MRI R2 and R2* mapping accurately estimates hepatic iron concentration in transfusion-dependent thalassemia and sickle cell disease patients. Blood 2005;106:1460-1465.

10. Armand P, Kim HT, Rhodes J, Sainvil MM, Cutler C, Ho VT, Koreth J, Alyea $E P$, Hearsey D, Neufeld EJ, Fleming MD, Steen $H$, Anderson D, Kwong RY, Soiffer RJ, Antin JH. Iron overload in patients with acute leukemia or MDS undergoing myeloablative stem cell transplantation. Biol Blood Marrow Transplant 2011;17:852-860.

11. Olthof AW, Sijens $P E$, Kreeftenberg HG, Kappert $P$, van der Jagt EJ, Oudkerk M. Non-invasive liver iron concentration measurement by MRI: comparison of two validated protocols. Eur J Radiol 2009;71:116-121.

12. Serai SD, Fleck RJ, Quinn CT, Zhang B, Podberesky DJ. Retrospective comparison of gradient recalled echo $\mathrm{R}^{*}$ and spin-echo R2 magnetic resonance analysis methods for estimating liver iron content in children and adolescents. Pediatr Radiol 2015;45:1629-1634.

13. Verlhac $S$, Morel $M$, Bernaudin $F$, Bechet $S$, Jung $C$, Vasile $M$. Liver iron overload assessment by MRI R2* relaxometry in highly transfused pediatric patients: an agreement and reproducibility study. Diagn Interv Imaging 2015;96:259-264.

14. Wermke $M$, Schmidt $A$, Middeke JM, Sockel $K$, von Bonin $M$, Schönefeldt C, Mair S, Plodeck V, Laniado M, Weiss G, Schetelig J, Ehninger G, Theurl I, Bornhäuser M, Platzbecker U. MRI-based liver iron content predicts for nonrelapse mortality in MDS and AML patients undergoing allogeneic stem cell transplantation. Clin Cancer Res 2012;18:6460-6468.

15. Yassin MA, Soliman A, De Sanctis V, Hmissi SM, Abdulla MAJ, Ekeibed $Y$, Ismail O, Nashwan A, Soliman D, Almusharaf M, Hussein R. The impact of iron overload in patients with acute leukemia and myelodysplastic syndrome on hepatic and endocrine functions. Acta Biomed 2018;89:18-22.

16. Ruccione KS, Wood JC, Sposto R, Malvar J, Chen C, Freyer DR. Characterization of transfusion-derived iron deposition in childhood cancer survivors. Cancer Epidemiol Biomarkers Prev 2014;23:1913-1919.

17. Vag T, Kentouche K, Krumbein I, Reichenbach JR, Lopatta E, Renz DM, Stenzel M, Beck J, Kaiser WA, Mentzel H. Noninvasive measurement of liver iron concentration at MRI in children with acute leukemia: initial results. Pediatr Radiol 2011;41:980-984.

18. Unal $S$, Cetin $M$, Hazirolan T, Yildirim $G$, Meral $A$, Birbilen $A$, Karabulut $E$, Aytac S, Tavil B, Kuskonmaz B, Tuncer M, Gumruk F. Number of erythrocyte transfusions is more predictive than serum ferritin in estimation of cardiac iron loading in pediatric patients with acute lymphoblastic leukemia. Leuk Res 2014;38:882-885.

19. Olcay L, Hazirolan T, Yildirmak Y, Erdemli E, Terzi YK, Arda K, Oztürkmen S, Akyay A, Kaymak-Cihan M, Biçakçi Z, Bal C. Biochemical, radiologic, 
ultrastructural, and genetic evaluation of iron overload in acute leukemia and iron-chelation therapy. J Pediatr Hematol Oncol 2014;36:281-292.

20. Olcay $L$, Serteser $M$, Kolay $M$, Balci HF, Yildirim ÜM, Tekgündüz $S A$, Hazirolan T, Terzi YK. The impact of iron overload in acute leukemia: chronic inflammation, but not the presence of nontransferrin bound iron is a determinant of oxidative stress. J Pediatr Hematol Oncol 2017;39:425-439.

21. de Ville de Goyet $M$, Moniotte $S$, Robert A, Dupont $S$, Vermylen $C$, Veyckemans $F$, Brichard B. Iron overload in children undergoing cancer treatments. Pediatr Blood Cancer 2013;60:1982-1987.

22. Schempp A, Lee J, Kearney S, Mulrooney DA, Smith AR. Iron overload in survivors of childhood cancer. J Pediatr Hematol Oncol 2016;38:27-31.

23. Alexopoulou E, Stripeli $F$, Baras $P$, Seimenis I, Kattamis A, Ladis V, Efstathopoulos E, Brountzos EN, Kelekis AD, Kelekis NL. R2 relaxometry with MRI for the quantification of tissue iron overload in beta-thalassemic patients. J Magn Reson Imaging 2006;23:163-170.

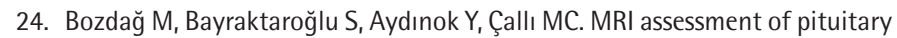
iron accumulation by using pituitary-R2 in beta-thalassemia patients. Acta Radiol 2018;59:732-739.

25. Au WY, Lam WM, Chu WC, Tam S, Wong WK, Pennell DJ, Lie AK, Liang R. A magnetic resonance imaging study of iron overload in hemopoietic stem cell transplant recipients with increased ferritin levels. Transplant Proc 2007;39:3369-3374.

26. Leung AW, Chu WC, Lam WW, Lee V, Li CK. Magnetic resonance imaging assessment of cardiac and liver iron load in transfusion dependent patients. Pediatr Blood Cancer 2009;53:1054-1059.

27. Viprakasit V, Ajlan A, Aydinok Y, Al Ebadi BAA, Dewedar H, Ibrahim AS, Ragab L, Trad O, Wataify AS, Wong LLL, Taher AT. MRI for the diagnosis of cardiac and liver iron overload in patients with transfusion-dependent thalassemia: An algorithm to guide clinical use when availability is limited. Am J Hematol 2018;93:135-137.

28. Maris TG, Papakonstantinou O, Chatzimanoli V, Papadakis A, Pagonidis K, Papanikolaou N, Karantanas A, Gourtsoyiannis N. Myocardial and liver iron status using a fast $T^{*} 2$ quantitative MRI (T*2qMRI) technique. Magn Reson Med 2007;57:742-753.

29. Bowen D, Culligan D, Jowitt S, Kelsey S, Mufti G, Oscier D, Parker J; UK MDS Guidelines Group. Guidelines for the diagnosis and therapy of adult myelodysplastic syndromes. Br J Haematol 2003;120:187-200.

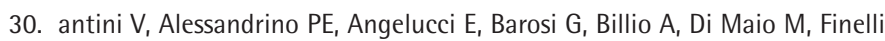
C, Locatelli F, Marchetti M, Morra E, Musto P, Visani G, Tura S; Italian Society of Hematology. Clinical management of myelodysplastic syndromes: update of SIE, SIES, GITMO practice guidelines. Leuk Res 2010;34:1576-1588.

31. Maximova N, Gregori M, Boz G, Simeone R, Zanon D, Schillani G, Zennaro F. MRI-based evaluation of multiorgan iron overload is a predictor of adverse outcomes in pediatric patients undergoing allogeneic hematopoietic stem cell transplantation. Oncotarget 2017;8:79650-79661.

32. Alessandrino $E P$, Angelucci $E$, Cazzola $M$, Porta $M G$, Di Bartolomeo $P$, Gozzini A, Malcovati L, Pioltelli P, Sica S, Bosi A. Iron overload and iron chelation therapy in patients with myelodysplastic syndrome treated by allogeneic stem-cell transplantation: report from the working conference on iron chelation of the Gruppo Italiano Trapianto di Midollo Osseo. Am J Hematol 2011;86:897-902.

33. Giagounidis A, Leto di Priolo S, Ille S, Fenaux P. A European survey on the detection and management of iron overload in transfusion-dependent patients with MDS. Ann Hematol 2011;90:667-673.

34. Amid A, Barrowman N, Vijenthira A, Lesser P, Mandel K, Ramphal R. Risk factors for hyperferritinemia secondary to red blood cell transfusions in pediatric cancer patients. Pediatr Blood Cancer 2013;60:1671-1675.

35. Kohgo $Y$, Ikuta $K$, Ohtake T, Torimoto $Y$, Kato J. Body iron metabolism and pathophysiology of iron overload. Int J Hematol 2008;88:7-15.

36. European Association for the Study of the Liver. EASL clinical practice guidelines for HFE hemochromatosis. J Hepatol 2010;53:3-22. 